\section{Dogwood Poinsettia [Euphorbia cornastra (Dressler) A. Radcliffe- Smith], A New Floral Pot Crop}

\author{
Alice Le Duc ${ }^{1}$ and Mary Lewnes Albrecht ${ }^{2}$ \\ KS 66506-5506 \\ Additional index words. new species, long-day plant, culture
}

Department of Horticulture, Forestry and Recreation Resources, 2021 Throckmorton Plant Science Center, Kansas State University, Manhattan,

The dogwood poinsettia can be associated with the traditional winter pointsettia crop but has pure-white bracts and gray-green foliage. As it shows strong potential as a new floral pot crop, we determined its response to daylength. The chief merit of the dogwood poinsettia, a recently discovered Euphorbia from Guerrero, Mexico (lat. $17^{\circ} 35^{\prime} \mathrm{N}$, long. $99^{\circ} 54^{\prime} \mathrm{W}$ ), is its pure-white bracts (Fig. 1) and summer flowering. Collected in 1973 and described as a new species (Dressler, 1975), the dogwood poinsettia's native habitat is tropical deciduous forests at high elevations (1930 m), where it is found growing in rich humus soil at the foot of large limestone outcrops. Although this species is similar to the Christmas poinsettia (E. pulcherrima Willd.) in growth habit and inflorescence, it differs in foliage characteristics. The dogwood poinsettia has hollow stems that arise from a woody basal trunk and may attain a height of $2 \mathrm{~m}$ or more. The true leaves, attached by reddish petioles, are dark graygreen with a white pubescence that is most pronounced on the abaxial surface. The terminal floral display of pure-white bracts surrounding a compound cyme can reach $13 \mathrm{~cm}$ in diameter.

An evaluation of the potential of this species as a floral crop was conducted using a systems approach (Armitage, 1986). The plant met phase I criteria by producing flowers within 16 weeks of initiation of the greenhouse production period and had an effective postharvest life of at least 1 week (for pot plants). The study then proceeded with phase II, propagation and production. Tip cuttings of actively growing shoots were taken in September, October, December, April, May, and June. Cuttings were 10 to $15 \mathrm{~cm}$ long and had two pseudowhorls of leaves. Rooting hormone (Hormodin 2; Merck \& Co., Rahway, N.J.) was applied to the base of each cutting before they were inserted in Oasis cubes

Received for publication 28 Sept. 1995. Accepted for publication 1 Mar. 1996. Contribution no. 9691-J of the Kansas Agricultural Experiment Station. The cost of publishing this paper was defrayed in part by the payment of page charges. Under postal regulations, this paper therefore must be hereby marked advertisement solely to indicate this fact.

${ }^{1}$ Assistant Professor.

${ }^{2}$ Professor. in $\approx 4$ weeks, when daylength was $>11 \mathrm{~h}$ (September, April, and May), with best rooting occurring at 12 to $13 \mathrm{~h}$ (April and May). Tip cuttings are recommended because cuttings without a terminal meristem may develop lateral shoots or even flower before rooting occurs. Propagation from seed also is possible; fresh seed germinated in 5 to 7 days with no special treatment required. Seedlings were extremely vigorous.

Growth chamber studies were initiated to determine suitable photoperiod conditions for active growth of plants. Established plants in 1-liter containers were placed in growth cham-
(Smither-Oasis, Kent, Ohio). Rooting occurred bers (16 plants in each), with photoperiods of $11.75,12.25$, and $12.75 \mathrm{~h}$. All chambers had 21C day/15C night cycles. Shoot count and length were recorded on days 38 and 56 of the experiment.

Statistical analysis showed that photoperiod had no significant effect on the number of lateral shoots that developed. However, lateral length, as measured after 56 days in the growth chamber, increased linearly with daylength (Fig. 2). Cyathia were visible after 56 days in the growth chambers and the experiment was terminated. Irrespective of photoperiod treatment, at flowering, each shoot had produced $15 \pm 2$ nodes below the inflorescence.

Under natural daylength conditions in Manhattan, Kan. (9.42 h on 2 Dec., 14.93 h on 22 June), once daylengths were $<10 \mathrm{~h}$ (16 Nov.) plants entered dormancy. Visible signs of growth were present when the daylength was $>11 \mathrm{~h}(22 \mathrm{Feb}$.). Plants produced flowers at terminals of all shoots within 2 months of shoot growth initiation. While actively growing, plants flowered every 2 to 3 months.

\section{Literature Cited}

Armitage, A.M. 1986. Evolution of new floricultural crops: A systems approach. HortScience 21:9-11

Dressler, R.L. 1975. A new and attractive poinsettia, Euphorbiaceae, from Guerrero, Mexico. Bol. Soc. Bot. Mexico 35:17.

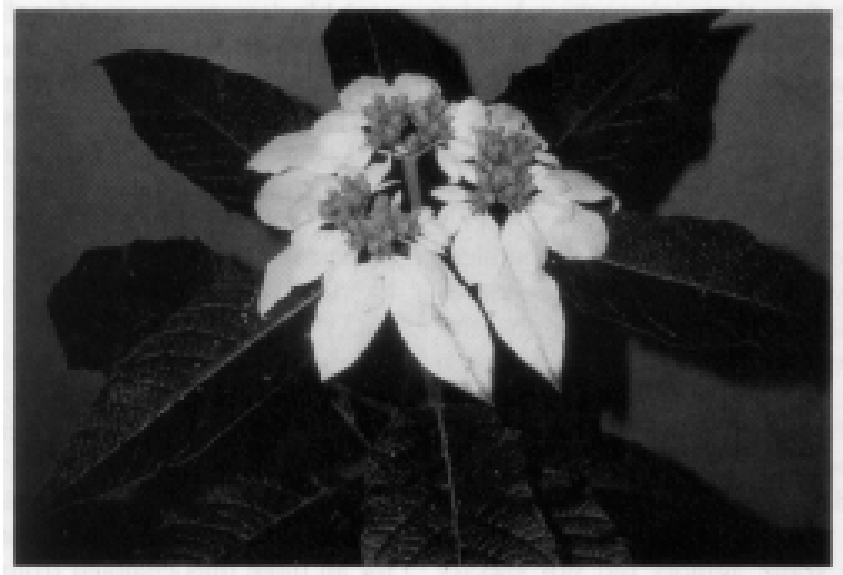

Fig. 1. Dogwood poinsettia inflorescence; diameter measures $13.5 \mathrm{~cm}$.

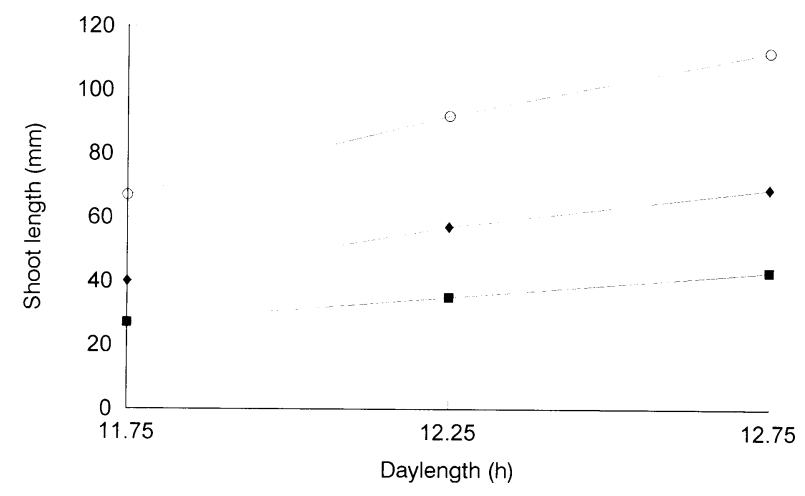

Fig. 2. (ロ) Initial shoot length of dogwood poinsettia, measured after 38 days in the growth chambers; $(\bigcirc)$ final measured after 56 days in the growth chambers; and $(\bullet)$ change in shoot length as a function of daylength. Initial length: $\mathrm{y}=18.7+8.0 \mathrm{x}(P>\mathrm{F}=0.0534)$; final length: $\mathrm{y}=45.4+22.4 \mathrm{x}(P>\mathrm{F}=0.0067)$; and change in shoot length: $\mathrm{y}=26.6+14.4 \mathrm{x}(P>\mathrm{F}=0.0067)$. 